\title{
Soviet basic science wins friends but also some enemies
}

\section{London}

IT has now emerged that Dr Gurii Marchuk, president of the Soviet Academy of Sciences, pleaded for more support for basic research in an address to the Special Conference of the Communist Party of the USSR last month. Marchuk's speech has just been published in full in Pravda.

Echoing $\mathrm{Mr}$ Mikhail Gorbachev's keynote speech, Marchuk declared that basic research, "the basis of all science and of all scientific and technical progress", had long been neglected (and inadequately supported) in the Soviet Union. The consequence is that Soviet science is "not entirely" ready to shoulder the tasks called for by perestroika.

In a frank comparison between Soviet science and that of the United States, Marchuk told the conference that, while the numbers employed in research may be roughly equal, the "capital-to-labour" ratio in the United States is at least three times as great as in the Soviet Union, with the result that US science is more productive.

Marchuk insisted that state funds will have to be the chief source of support for basic research, dismissing in the process the claims of those who have been urging "cooperative measures" for the support of science. But he also followed $\mathrm{Mr}$ Gorbachev's argument that science will be effective only if it is rid of "petty tutelage" and interference.

He urged that holders of all major posts in the scientific establishment (including himself) should be elected and hold office for no more than 10 years. To promote glasnost in science, he is also planning to put to the Soviet government in the near future a plan for a weekly science newspaper.

Dr Evgenii Chazov, all-union minister of health and another speaker at the special conference, complained of the misdirection of funds during the Brezhnev "era of stagnation", complaining of the frequent boasts that the Soviet Union had more physicians and hospitals than any other country although it came fiftieth in the world in the infant mortality league, behind Mauritius and Barbados and thirtysecond in the life-expectancy tables.

Chazov also told the conference the story of the town of Tynda, on the new Baikal--Amur mainline railway whose local authority built a railway station in marble and aluminium to impress visiting delegations, but left the regional hospital in a series of army huts.

The rector of Moscow University, Dr Anatolii Logunov, pleaded for more money: "We are absolute paupers in modern equipment", he said, and went on to complain that even the university's attempt to buy up-to-date computers of Soviet manufacture had enmeshed it in negotiations with the all-union ministry of finance.

Logunov also complained that the "Lysenko virus" is still alive, and that "certain people try to silence others who think differently". That may have been a heartfelt remark; Logunov is himself the author of a theory of relativity that commands few friends. Logunov asked that the universities should have "their hands untied" by dispensing with the State Committee for Public Education, formed only last autumn. He urged a broad programme of international cooperation to allow hundreds of thousands of Soviet students to study abroad, not just ones and twos as at present.

Not all those who addressed the special conference were as trustful. The director of the Ivanovo Machine Building Production Association, $\mathrm{Mr}$ Kabaidze, reproached Academician Marchuk for not demanding that science should be self financing. $\mathrm{He}$ complained that Soviet industry had to support too many research institutes which, with a few exceptions, were failing to produce results, and said that a vast state research sector was not necessarily the best way to produce the high technology on which the future depends. "I don't think I've ever heard of the South Korean Research Institute", he said, "but South Korea is now in the top ten of the industrialized nations".

The newly established State Committee for the Protection of the Environment complained through its president, Dr F.T. Morgun, that scientists themselves are responsible for many of the Soviet Union's environmental problems. Borys Oleynek, chairman of the Ukrainian Writers' Union, was fearful for what would happen when the Danube-Dnieper Canal would discharge "all of Europe's effluent" into the Ukraine's chief river, and also complained that public anxiety about nuclear power stations had not been taken seriously enough.

Even if the balance of the science presentations to the special conference may have been in favour of autonomy and local decision-making, not all the talk went that way. Thus Academician Primakov, from the Soviet Academy's Institute of the World Economy, attacked the notion that each of the Soviet republics should run its own research programme, regardless of resources and personnel. Rather, Primakov said, Soviet science should be "an integrating force" in Soviet life.

\section{Trust in Trinity}

TRINITY College, Cambridge is to set up a trust fund to help Cambridge University out of its financial difficulties. The 28 Cambridge colleges, some of which have substantial fortunes, have till now kept their finances separate from the university, which is funded by the government. Now Trinity is setting a precedent by stepping in to help the university which has suffered under cutbacks in government funding. The trust, to be called the Isaac Newton Trust, will be complementary to the university's own trust and will set apart several million pounds to benefit education and research in the university. Trinity hopes this will set an example which other colleges may follow.

C.McG.

\section{Tired of waiting}

THE "secrecy barrier" on Jewish scientists wishing to emigrate from the Soviet Union may be reduced to five years, according to participants in a seminar of the International Bar Association in Moscow. Rumours of such a change have been current in Moscow for some time, and Soviet officials told the lawyers that there was "some truth" in them. But implementing the changes, the officials said, will be a long process, as hard-line bureaucrats, opposed to Mikhail Gorbachev's reforms, are trying to block it - it may take longer than five years to introduce the "five-year upper limit".

Jewish refusnik scientists in Moscow are sceptical about the alleged changes. Although the number of scientists allowed to emigrate has increased considerably in the past few months, the refusniks point out that these were predominantly from the backlog of cases where the scientist concerned had been so long out of professional employment (in some cases as long as $\mathbf{1 5}$ years) that to claim that he or she still possessed "secret" information was simply ludicrous. People whose cases are regarded by the authorities as more "complicated" are now being told that they cannot expect a decision before 1992. Moreover, the concept of the 'brain drain', normally applied to the developing nations, is still being invoked by some Soviet officials. V.R.

\section{Inquiry completed}

ThE planned inquiry into the conduct of the experiments reported in Nature two weeks ago by Dr Jacques Benveniste was conducted in Paris last week. Those who visited his laboratory were $\mathrm{Mr}$ James Randi, the professional magician who is also a Macarthur Fellow, his assistant $\mathrm{Mr}$ José Alvarez, the editor of Nature, Mr John Maddox, and Mr Walter W. Stewart from the Institute of Allergy and Infectious Diseases of the US National Institutes of Health. In consultation with $\mathrm{Dr}$ Benveniste, a report will be published in Nature on 28 July. 